\title{
Computer literacy of young people in Serbia and regional differences
}

\author{
Tatjana StojanovićA , Ivana Penjišević ${ }^{B *}$, Tamara Lukićc ${ }^{C}$, Jelena Živković ${ }^{D}$ \\ Received: November 23, 2016 | Revised: December 14, 2016 | Accepted: March 19, 2017
}

DOI: $10.18421 / G P 21.01-04$

\begin{abstract}
The purpose of the paper is highlighted phenomenon of computer self-literate. Research confirmed that the school influence is not meritorious for computer literacy. Analysis of statistical data about computer literacy of the young in Serbia has found the regional differences in number, gender and age structure. Attitudes were formed in function to describe the opinions of young about this phenomenon. Four hundred young from different parts of Serbia gave the opinion about the importance, overcoming, expansion, consequence, future development of computer self literacy. Results of research represent contribution knowledge about characteristics of young in Serbia on the beginning of the 21stcentury and they can be used for interregional comparison.
\end{abstract}

Keywords: computer literacy, region, Serbia, the young, regional differences

\section{Introduction}

Following the computer literacy in Serbia started by Census of 2011. It was defined as capability of person to use the basic computer applications for doing everyday tasks. Regarding that were gathered data if the person knows how to do processing of text, make tables, sends and receives e-mails as well as if the person knows to use Internet (RZS, 2013). The greatest part of the young in Serbia, from 15 and 29 years, during their schooling had not this kind of becoming literate. According to received data, there are $88.4 \%$ of the young in Serbia who are computer literate. It shows the existence of self-literate phenomenon. It was possible because computer literacy starts with classic literacy. Besides, one of the most important aims of the idea about appliance of electronic literacy was the mass. It was possible to be achieved only by making software programs which everybody could easily overcome. The aim of the paper is to show how much the young were focused on computer literacy and their attitude about its importance, overcoming, expanding and future development. In addition, their education period 'corresponds' to the time of mass appearance of computers in Serbia. In the future, statistics will monitor computer literacy as one of the characteristics of the population. Therefore we can say that this paper represents one of the first-born of research of this type in Serbia.

\section{Theoretical background and Previous Research}

In the world of highly developed technology, first of all, literacy refers to 'computer literacy', respectively, capability to find out, learn and interpret in the world of multimedia messages by new multimedia language which includes not only written word, speech, but also sound and picture (Matović, 2011). Computer litera-

\footnotetext{
A "Veljko Petrović" High School, 25000 Sombor, Serbia; tatjanagea@gmail.com

B University of Priština temporary situated in Kosovska Mitrovica, Faculty of Sciences, Institute of Geography, Lole Ribara 29, 38220 Kosovska Mitrovica, Tel.: 0038166-800-64-67, Serbia; ivanasocanac@yahoo.com

c University of Novi Sad, Faculty of Sciences, Department of Geography, Tourism and Hotel Management, Trg Dositeja Obradovića 3, 21000 Novi Sad, Serbia; snstamara@yahoo.com,

D University of Niš, Faculty of Sciences and Mathematics,Višegradska 33, 15000 Niš, Serbia; zivkovic.s.jelena@gmail.com

* Corresponding author: Ivana Penjišević, e-mail: ivanasocanac@yahoo.com
} 
cy draws attention of the scientists of various scientific disciplines. It is defined as 'capability to use computers and computer programs' (Nadrljanski, 2006). Computer literacy indicates the knowledge of using information communication technology and its tools as well as the possibility of permanent upgrading in the sense of technology innovations (Rašidović, 2013). Computer literacy Dijanošić (2008) as distinguished from the secondary so called functional literacy (understanding of written instructions in everyday life, for example: usage of some products, contract fulfillment, or forms, understanding of social movements and similar) classifies them into the third literacy together with new technologies: informatics, Internet and SMS. Computer literacy is important for using of great number of information which were given and circulate thanks to media (Zindović-Vukadinović, 1995).

Research related to Computer Literacy is of ten related to the population under the age of 19 years (Bovée, et al., 2007). Young from developed part of world is already completely finished in computer literacy. According the edition of Buckingham and Willett (2013) young are called digital generation. Mainly, young use computers for fun. Williamson (2009) explored about young, computer games and schools. Byron Review (2008) supplying evidence of how and why some schools are beginning to explore the use of games for formal educational purposes. Livingstone, Helsper (2007) analyses findings from a national survey of UK that reveal inequalities by age, gender and socioeconomic status in relation to their quality of access to and use of the internet. Research related to computer literacy is often related to the population under the age of 19 years. Bearing in mind that Serbia is working on that computer literacy becomes available in all of its schools, but also that it has not, it can be said that lags behind the developed world. According the ICT Development Index (IDI), in 2015 Serbia

Table 1. The International Telecommunication Union (ITU) Information and communication technology (ICT) development index for Serbia and its surrounds

\begin{tabular}{|l|c|c|c|c|}
\hline Country Rank & $\begin{array}{c}2010 \\
\text { IDI }\end{array}$ & $\begin{array}{c}2010 \\
\text { Rank }\end{array}$ & $\begin{array}{c}2015 \\
\text { IDI }\end{array}$ & $\begin{array}{c}2015 \\
\text { Rank }\end{array}$ \\
\hline $\begin{array}{l}\text { Bosnia and } \\
\text { Herzegovina }\end{array}$ & 4.28 & 75 & 5.28 & 77 \\
\hline Bulgaria & 5.45 & 47 & 6.52 & 50 \\
\hline Croatia & 5.82 & 42 & 7.00 & 42 \\
\hline FYR Macedonia & 4.96 & 57 & 6.07 & 60 \\
\hline Hungary & 5.92 & 41 & 6.82 & 48 \\
\hline Montenegro & 4.89 & 60 & 5.90 & 65 \\
\hline Romania & 4.99 & 55 & 6.11 & 59 \\
\hline Serbia & 5.29 & 51 & 6.45 & 51 \\
\hline
\end{tabular}

Source: http://www.itu.int/net4/ITU-D/idi/2015 was on the 51stposition on the world (Table 1). Since 2010, the position has not changed. Except Romania, the countries in the region belonging to the European Union are the better positioned than Serbia.

\section{Data, Methods and Variables}

In the first part of the paper were analyzed existing data about computer literacy of the young in Serbia which were gathered by the Statistical Office of the Republic of Serbia.By the analysis was established regional differences as well as differences in number and sex age structure of computer literacyyoungof the age from 15 to 29 years.

In the second part were considered the attitude of young peopleabout the importance, overcoming and spreading future development of the computer literacy. Attitudes were measured on a five-point Likert type scale ranging from 1 (strongly disagree) to 5 (strongly agree). The interview was conducted during the autumn 2014, in 57 municipalities (Figure 1). Results were analyzed by descriptive statistics and using T-test, one-factor analysis of ANOVA variance and Post-hoc Tukey HSD test. T-test was made with independent samples and compared by arithmetic mean of two groups. As it was not possible to assume the result of comparison,two tailed test was used.

\section{Simple}

Raosoft (2004) calculator was used for checking the adequacy of sample size. Accordingly, for size of population, in this case of young people in Serbia 1.322.021, at confidence level of $95.0 \%$ was recommended sample size of 385 . Taking into consideration that investigation covered 500 examinees of which 416 filled questionnaires correctly (83.2\%), the sample was considered as representative. The age categories were formed by dividing the young at equal parts (15-29), respectively, those who most often belong to secondary school students (15-19), students (20-24) or others (25-29).Tendency was to have all of them adults in order to avoid the procedure for getting the agreement by their parents concerning the investigation. Therefore, all examinees of age category $15-19$ have 18 or 19 years (Table 2).

The majority of examinees $(51.4 \%)$ have got their first computer during elementary school education (Table 2). The average age of getting the computer is 10.8 years. If it was considered by the regions, children from Belgrade region was the first one who possessed the computer, immediately before started going to school (age of 6.7 years). Children from the Region of South and East Serbia get the computers latest (with 13.0 years). All examinees started using of computers before they enrolled the secondary schools. 
Table 2. Socio demographic features of respondents and the average age of getting the computer

\begin{tabular}{|c|c|c|c|}
\hline \multicolumn{2}{|l|}{ Simple size: 416} & $\%$ & Age \\
\hline \multicolumn{4}{|l|}{ Gender } \\
\hline \multicolumn{2}{|l|}{ Male } & 48.6 & 10.4 \\
\hline \multicolumn{2}{|l|}{ Female } & 51.4 & 12.1 \\
\hline \multicolumn{4}{|l|}{ Age categories } \\
\hline \multicolumn{2}{|l|}{$15-19$} & 42.8 & - \\
\hline \multicolumn{2}{|l|}{$20-24$} & 41.8 & - \\
\hline \multicolumn{2}{|l|}{$25-29$} & 15.4 & - \\
\hline \multicolumn{4}{|l|}{ Regions } \\
\hline \multicolumn{2}{|c|}{ Region of Vojvodina } & 37.5 & 10.6 \\
\hline \multicolumn{2}{|l|}{ Belgrade Region } & 16.8 & 6.7 \\
\hline \multicolumn{2}{|c|}{ Region of Šumadija and West Serbia } & 28.9 & 12.7 \\
\hline \multicolumn{2}{|c|}{ Region of South and East Serbia } & 16.8 & 13.0 \\
\hline \multicolumn{4}{|l|}{ Education } \\
\hline \multicolumn{2}{|l|}{ Primary school } & 33.7 & - \\
\hline \multicolumn{2}{|l|}{ High school } & 47.6 & - \\
\hline \multicolumn{2}{|l|}{ Faculty } & 18.7 & - \\
\hline \multicolumn{4}{|c|}{ Time of arrivalinpossession ofa computer } \\
\hline Before & \multirow{3}{*}{ primary school } & 26.9 & - \\
\hline During & & 51.4 & - \\
\hline After & & 21.6 & - \\
\hline
\end{tabular}

Source: Survey

\section{Research area}

Administratively, Serbia is divided in five NUTS 2 regions. In one of those, the Region of Kosovo and Metohija, census was not conducted because of the political reasons, so there are no data. Figure 1 show territorial distribution of municipalities in which the research was conducted.

\section{Results and Discussion}

\section{Computer Literacy in Serbia}

The participation of the young computer literate is the largest one in Belgrade region (91.7\%), and minimum in the Region of the South and East Serbia (84.7\%). Respectively, in Belgrade region was 14.7 times more computer literate than illiterate, while the value in the Region of the South and East Serbia was 5,5 (Figure 2). About half of computer illiterate were at the age category between 25-29 years, respectively, the oldest age category regarding the age of young people. As the age category is younger, the share of young computer illiterate is less (Table 3).

The largest share of the young $(50,5 \%)$ that were computer literate is among their oldest category (2529 years). However, differences concerning the share size of the young that were computer literate are small

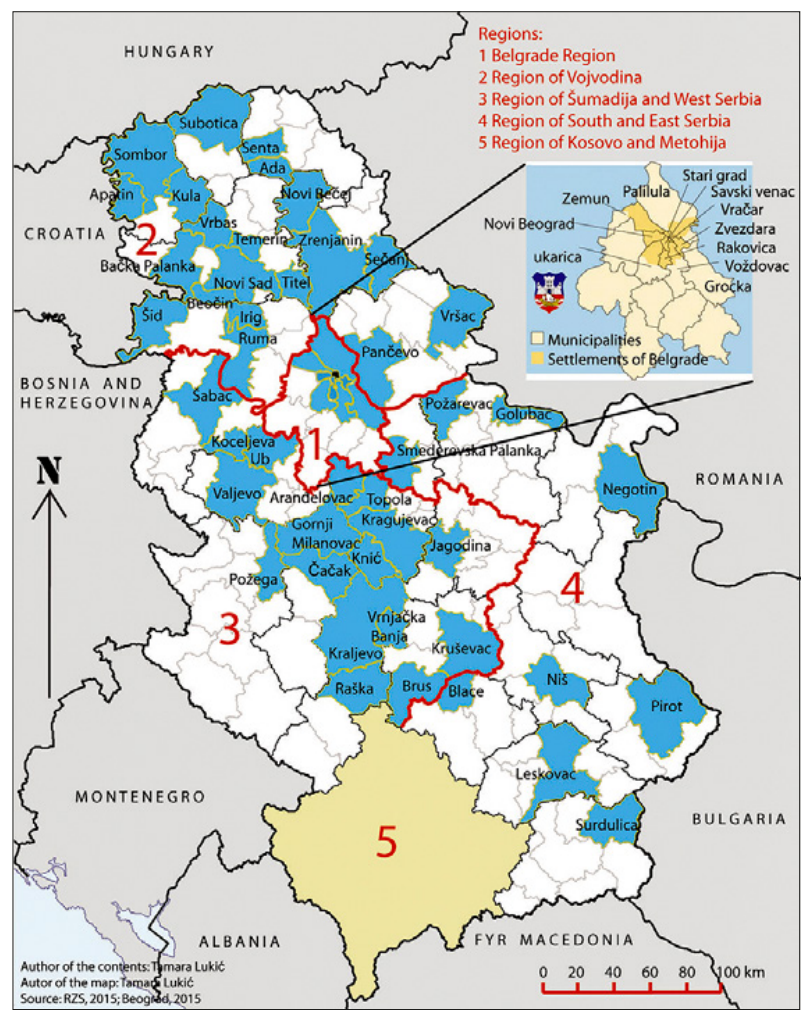

Figure 1. Geographic position of municipalities where the research was conducted

regarding age categories. The values and share relations in Belgrade region and the Region of Vojvodina are similar to the values at the Republic level. In the Region of the South and East Serbia the share of the young computer literate declines with increasing of years, this is reversed situation in the largest part of Serbia. It shows the later development of consciousness about necessity to develop computer literacy in this region influenced by the economy factors and perhaps some technical conditions that were precondition for internet development.

Young men in Serbia prevail among computer illiterate $(51.1 \%)$ as well as among computer literate $(51.2 \%)$ of young people. The difference in share of men and women is very small on the republic level as well as on the regional level. Only in Belgrade Region young women were more computer literate (50.2\%). Differences were more expressed by the type of settlements. Almost 2/3 of the young illiterate $(63.3 \%)$ lives outside of the city area. Similar share of young computer literate $(64.5 \%)$ mostly live in the cities. The majority of the young computer illiterate are in rural areas, except in the Belgrade Region where the most young illiterate live in the city area (60.1\%). Belgrade Region has a small number of settlements that do not belong to the city area in comparison to the other regions of Serbia. Computer literate young inhabitants are numerous in the city than 
Table 3. Young according to computer literacy, per age categories and regions of Serbia, Census 2011 (\%)

\begin{tabular}{|c|c|c|c|c|c|c|c|}
\hline \multicolumn{4}{|l|}{ Illiterate } & \multicolumn{4}{|l|}{ Literate } \\
\hline Total & $15-19$ & $20-24$ & $25-29$ & Total & $15-19$ & $20-24$ & $25-29$ \\
\hline \multicolumn{8}{|c|}{ Republic of Serbia } \\
\hline 153.284 & 18.9 & 30.6 & 50.5 & 1.168 .737 & 31.9 & 33.6 & 34.5 \\
\hline \multicolumn{8}{|c|}{ Belgrade Region } \\
\hline 19.582 & 18.8 & 29.6 & 51.6 & 288.116 & 28.1 & 32.1 & 39.8 \\
\hline \multicolumn{8}{|c|}{ Region of Vojvodina } \\
\hline 38.239 & 19.2 & 30.4 & 50.4 & 325.083 & 31.5 & 33.7 & 34.8 \\
\hline \multicolumn{8}{|c|}{ Region of South and East Serbia } \\
\hline 42.783 & 20.4 & 30.8 & 48.8 & 236.159 & 34.5 & 34.1 & 31.4 \\
\hline \multicolumn{8}{|c|}{ Region of Šumadija and West Serbia } \\
\hline 52.680 & 17.3 & 31.0 & 51.7 & 319.379 & 33.9 & 34.6 & 31.5 \\
\hline
\end{tabular}

Source: RZS, 2013; own calculations

other settlements at the republic level and in all regions. Beside various advantages of city areas where computer literacy is more expanded, it can be said that possibility for using internet free of charge at the university libraries and at public places such as city squares, parks and similar greatly contributed to it. Young computer illiterate women were more dominant in the urban settlements while the young computer illiterate men were numerous in other settlements. Young, computer literate men are numerous in the cities and other settlements in Serbia as well as in all its regions (RZS, 2013; Bubalo Živković, Lukić, 2015).

\section{Attitudes Concerning Computer Literacy}

Following results were received by checking of seven attitudes on the level of Serbia. The examinees did not completely agree with neither of attitude. They agreed with five attitudes, the opinions were divided about one attitude but they did not agree with one attitude (Figure3).

T-test did not establish statistically significant differences, at the importance level $\mathrm{p}<0.01(\mathrm{t} \geq 2.57)$ (Pearson and Hartley, 1966), between genders of examinees in neither attitude. In the most attitudes young women have shown higher level of agreement in comparison to young men. The replies of young men examinees have higher average values concerning the question of fear from using the computer software in future and by noticing the phenomenon of presence greater number of foreign words in Serbian language. Young Men have shown disagreement also with attitudes: Computer literacy has negative influence on observation of spelling rules and school is the most meritorious for computer literacy.

The investigators such as Lajoie and Derry (2013), Rosenberg (2013), Bolter (2014) and others wrote

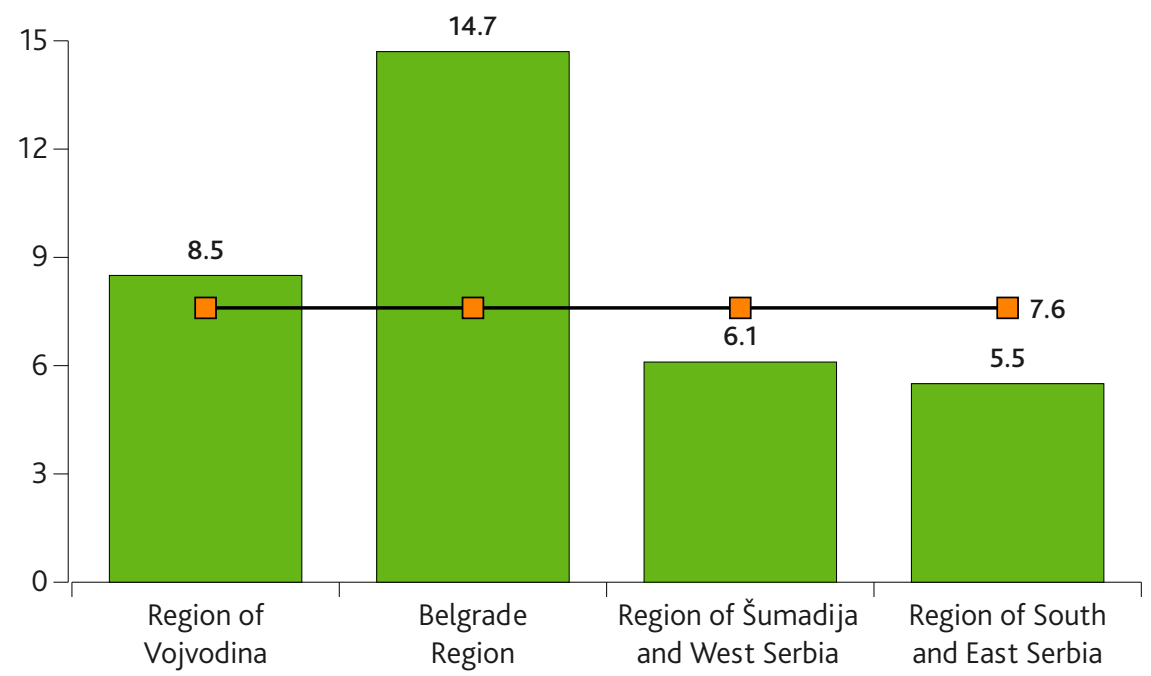

Figure 2. How many times is more computer-literate young from illiterate young, in Serbia and its regions, Census 2011, ratio Source: RZS, 2013 
Computer literacy enabled disrespect of spelling rules (attitude 7)

Computer literacy has 'brought' many foreign words (attitude 6)

I am not sure that I will be able to follow in future further development of computer literacy (attitude 5)

School is the most meritorious for computer literacy (attitude 4)

I am sure that I could help anybody to become computer literate (attitude 3 )

Computer literacy

can be easily surmounted (attitude 2)

Modern life cannot be imagined without computer literacy (attitude 1)
1.17

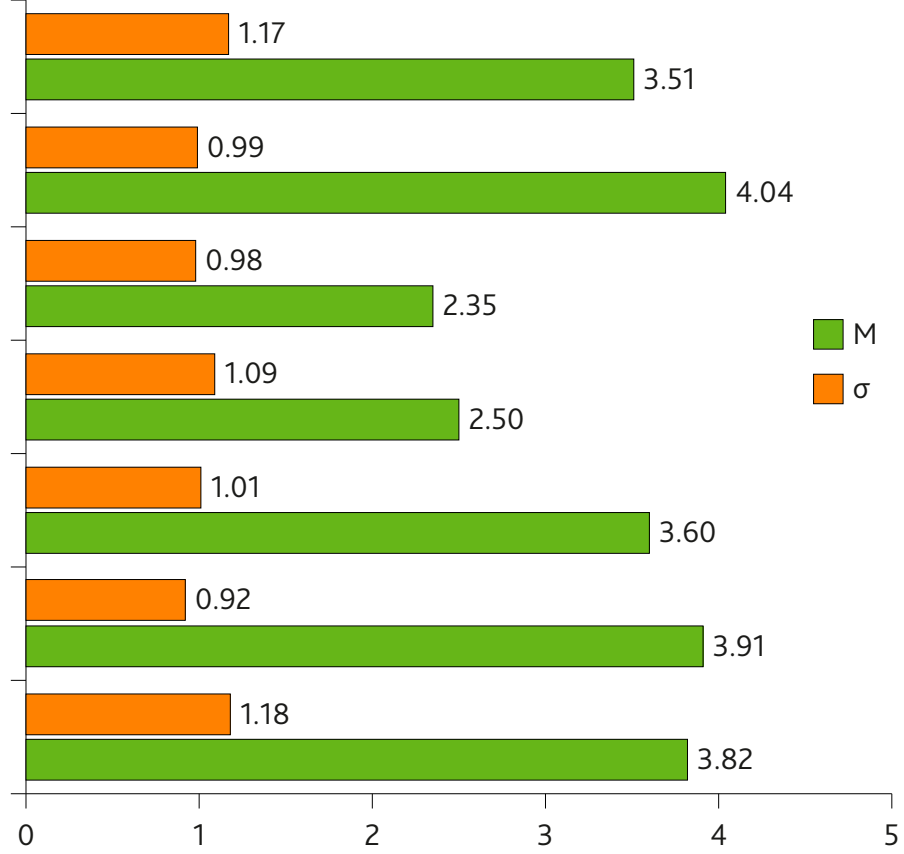

Figure 3. Mean value and standard deviation for attitudes Source: Survey

about importance and possibilities of using computer literacy in various spheres of life. Young people in general agreed with the attitude that modern life cannot be imagined without computer literacy $(M=3.82)$ but it was found that they did not mutually agree $(\sigma=1.18)$. Statistically significant differences among age categories of the young were established by one-factor analysis of ANOVA variance of the examinees age (Table 4). Post-hoc Tukey HSD test has shown that the young of the oldest age category (25-29) completely agreed with this attitude while the others have shown only simple agreement (Table 6). Beside that the young of age category 25-29 years had very high level of mutual agreement $(\sigma=0.50)$. In the group of the young of this age category dominated those who had already completed their schooling and were in the process of looking for a job, or have already been working. Being informed about situation in the society, they have noticed, as they said, that computer literacy is the condition for getting a job even if it was not used in working process (Maksimović, 2006; Radojković, 2007; Gubin, 2010; Unković, Stakić, 2011; Mikarić, Trajković, 2013). Modern scientific researches are impossible without using a computer. For example, it is most evident in the papers of geographers, whose research results are applicable in nature (Lukić, et al., 2013; Micić, et al., 2014; Obreht, et al., 2014) as well as in society (Đukičin, et al., 2014; Milošević, Đorđević, 2015).

Young people have shown agreement $(\mathrm{M}=3.91)$ and high level of mutual agreement $(\sigma=0.92)$ that computer literacy can be easily surmounted. One examinee explained it as follows: 'Using of computers must be simple if the aim is to achieve their wide appliance in all society spheres'. There are traces, also in literature about simplicity of surmounting usage of computers. For example, Davis et al. (1992), Duka et al. (2009), Dimovand, Zdravev (2011), Akgun et al. (2012), Holmquist (2013) and Patterson and Hennessy (2013) wrote about it.

The young in Serbia are sure that they could help everybody in computer literacy $(\mathrm{M}=3.60)$ and almost agreed completely $(\sigma=1.01)$. Readiness for help in computer literacy was expected, taking into consideration the attitude about its easiness for overcoming it. Young women were more willing to help but the level of mutual agreement was higher with young men, according to t-test. One-factory analysis of ANOVA variance has shown the existence of statistically significant differences with the youngest age category of young people (15-19). They were not sure that could help to everybody $(\mathrm{M}=3.34)$ and mutually agreed about this attitude $(\sigma=1.00)$. There were statistically significant differences among the regions. Post-hoc Tukey HSD test separated the biggest difference between the examinees from Vojvodina and those from Belgrade region (Table 7). The young from Vojvodina, in comparison to the other regions were the most sure who could help in computer literacy $(\mathrm{M}=3.77)$. They were all in agreement about their attitude $\sigma=0.88$ (Table 5).

However, the young from Belgrade region were in agreement that they were not sure $(M=3.29, \sigma=1.01)$. Those two regions are physically in touch, but each of them has certain characteristics. The Region of Vo- 
Table 4. Factor analysis of attitudes about computer literacy per age categories of young (for $F$ $(2,413)$, critic values according to Snedecor and Cochran table (1980), $p<0.01 ; F \geq 3.47$ )

\begin{tabular}{|c|c|c|c|c|c|}
\hline Attitudes & Years & M & $\sigma$ & $F$ & $p$ \\
\hline \multirow{3}{*}{$\begin{array}{l}\text { Modern life cannot be imagined without } \\
\text { computer literacy. }\end{array}$} & $15-19$ & 3.66 & 1.26 & \multirow{3}{*}{11.03} & \multirow{3}{*}{0.0001} \\
\hline & $20-24$ & 3.76 & 1.22 & & \\
\hline & $25-29$ & 4.44 & 0.50 & & \\
\hline \multirow{3}{*}{$\begin{array}{l}\text { Computer literacy can be easily } \\
\text { surmount. }\end{array}$} & $15-19$ & 3.76 & 1.01 & \multirow{3}{*}{4.22} & \multirow{3}{*}{0.0150} \\
\hline & $20-24$ & 4.01 & 0.85 & & \\
\hline & $25-29$ & 4.06 & 0.79 & & \\
\hline \multirow{3}{*}{$\begin{array}{l}\text { I am sure that I could help anybody to } \\
\text { become computer literate. }\end{array}$} & $15-19$ & 3.34 & 1.00 & \multirow{3}{*}{12.51} & \multirow{3}{*}{0.0001} \\
\hline & $20-24$ & 3.74 & 0.98 & & \\
\hline & $25-29$ & 3.97 & 0.96 & & \\
\hline \multirow{3}{*}{$\begin{array}{l}\text { School is the most meritorious for } \\
\text { computer literacy. }\end{array}$} & $15-19$ & 2.41 & 1.13 & \multirow{3}{*}{3.12} & \multirow{3}{*}{0.045} \\
\hline & $20-24$ & 2.66 & 0.86 & & \\
\hline & $25-29$ & 2.34 & 0.86 & & \\
\hline \multirow{3}{*}{$\begin{array}{l}\text { I am not sure that I will be able to } \\
\text { follow in future further development of } \\
\text { computer literacy. }\end{array}$} & $15-19$ & 2.08 & 0.78 & \multirow{3}{*}{15.72} & \multirow{3}{*}{0.0001} \\
\hline & $20-24$ & 2.64 & 1.09 & & \\
\hline & $25-29$ & 2.31 & 0.96 & & \\
\hline \multirow{3}{*}{$\begin{array}{l}\text { Computer literacy has 'brought' many } \\
\text { foreign words. }\end{array}$} & $15-19$ & 3.90 & 1.08 & \multirow{3}{*}{6.94} & \multirow{3}{*}{0.0011} \\
\hline & $20-24$ & 4.25 & 0.84 & & \\
\hline & $25-29$ & 3.88 & 1.00 & & \\
\hline \multirow{3}{*}{$\begin{array}{l}\text { Computer literacy enabled disrespect of } \\
\text { spelling rules. }\end{array}$} & $15-19$ & 3.25 & 1.23 & \multirow{3}{*}{12.61} & \multirow{3}{*}{0.0001} \\
\hline & $20-24$ & 3.84 & 1.07 & & \\
\hline & $25-29$ & 3.34 & 1.06 & & \\
\hline
\end{tabular}

Source: Survey and own calculations

jvodina was settled even by about twenty one ethnic group. It separates in the region as the area so called 'Europe in small' (Lukić, et al., 2014). Cohabitation of ethnic groups in Province of Vojvodina is carried out through permanent exchange of experience and culture influence. The results of such exchange show the peculiarity of the Province of Vojvodina (Lukić, et al., 2014a).

The young of Serbia haven't got clear opinion about the attitude that the school is the most meritorious for computer literacy. The average value of their answer is at the edge with value which already belongs to disagreement $(M=2.50)$, beside that, they almost mutually agree $\sigma=1.09$ (Figure 3). This answer initiated beginning of this research. By interacting with them could be concluded that faddishness is mostly meritorious for computer literacy, and then various forms of entertainment and rivalry. The young who did not have computers during their primary school said that they were sorry, that they later experienced as a disadvantage in continuing their education. It had negative influence for choosing their future occupation, but when they purchased the personal computer, it annulled necessity to have the computer at school. The young who used computers at the certain level of their schooling pointed out that their experience was almost useless because the program languages, as they learned them at school, were often out-of-date or they had narrow application (BASIC, LOTUS, PASKAL, etc.). All of them agreed that computer literacy should be present in the curriculum as the subject at the beginning of schooling as well the method in educational process. This subject should, also be well outlined, respectively, plan and program should 'keep pace with time' when teaching. Delić (2008) pointed out that schools equipping with contemporary computers and informatics literacy represent one of the priorities of educational system reform.

The examinees did not sure that they will be able to follow in future further development of computer literacy $(M=2.35)$ and they have shown great level of mutual agreement $\sigma=0.98$ (Figure 3). Knowledge and skill of computer literacy should be expanded and improved every day because development of information and communication technology is quickly developing (Delić, 2008). Post-hoc Tukey HSD test has shown that the greatest difference appeared between examinees of age 15-19 and 20-24 years (Table 6). Such result might influence oversized fear from unknown. It appears as a consequence of awareness of improvement of information technologies. Age groups of students and the oldest group of the young are in the position 
Table 5. One-factor analysis of attitudes of young people about computer literacy per region

\begin{tabular}{|c|c|c|c|c|c|}
\hline Attitudes & Region & $M$ & $\sigma$ & $\mathrm{F}$ & $P$ \\
\hline \multirow{4}{*}{$\begin{array}{l}\text { Modern life cannot be } \\
\text { imagined without computer } \\
\text { literacy. }\end{array}$} & Belgrade & 4.00 & 0.87 & \multirow{4}{*}{1.472} & \multirow{4}{*}{0.22} \\
\hline & S and $E$ SRB & 3.83 & 1.51 & & \\
\hline & Šumadija and W SRB & 3.65 & 1.31 & & \\
\hline & Vojvodina & 3.87 & 1.02 & & \\
\hline \multirow{4}{*}{$\begin{array}{l}\text { Computer literacy can be } \\
\text { easily surmount. }\end{array}$} & Belgrade & 3.86 & 0.77 & \multirow{4}{*}{0.784} & \multirow{4}{*}{0.50} \\
\hline & S and $E$ SRB & 3.83 & 1.14 & & \\
\hline & Šumadija and W SRB & 3.88 & 0.97 & & \\
\hline & Vojvodina & 4.00 & 0.84 & & \\
\hline \multirow{4}{*}{$\begin{array}{l}\text { I am sure that I could } \\
\text { help anybody to become } \\
\text { computer literate. }\end{array}$} & Belgrade & 3.29 & 1.01 & \multirow{4}{*}{3.821} & \multirow{4}{*}{0.01} \\
\hline & $S$ and $E S R B$ & 3.57 & 1.16 & & \\
\hline & Šumadija and W SRB & 3.58 & 1.04 & & \\
\hline & Vojvodina & 3.77 & 0.88 & & \\
\hline \multirow{4}{*}{$\begin{array}{l}\text { School is the most } \\
\text { meritorious for computer } \\
\text { literacy. }\end{array}$} & Belgrade & 2.46 & 1.09 & \multirow{4}{*}{1.436} & \multirow{4}{*}{0.23} \\
\hline & S and $E$ SRB & 2.40 & 1.28 & & \\
\hline & Šumadija and W SRB & 2.40 & 1.04 & & \\
\hline & Vojvodina & 2.64 & 1.04 & & \\
\hline \multirow{4}{*}{$\begin{array}{l}\text { I am not sure that I will } \\
\text { be able to follow in future } \\
\text { further development of } \\
\text { computer literacy. }\end{array}$} & Belgrade & 2.11 & 0.79 & \multirow{4}{*}{5.430} & \multirow{4}{*}{0.001} \\
\hline & $S$ and $E$ SRB & 2.06 & 0.96 & & \\
\hline & Šumadija and W SRB & 2.52 & 1.11 & & \\
\hline & Vojvodina & 2.46 & 0.92 & & \\
\hline \multirow{4}{*}{$\begin{array}{l}\text { Computer literacy has } \\
\text { 'brought' many foreign } \\
\text { words. }\end{array}$} & Belgrade & 4.14 & 0.64 & \multirow{4}{*}{14.320} & \multirow{4}{*}{0.0001} \\
\hline & S and E SRB & 3.37 & 1.38 & & \\
\hline & Šumadija and W SRB & 4.22 & 0.92 & & \\
\hline & Vojvodina & 4.17 & 0.83 & & \\
\hline \multirow{4}{*}{$\begin{array}{l}\text { Computer literacy enabled } \\
\text { disrespect of spelling rules. }\end{array}$} & Belgrade & 3.43 & 1.08 & \multirow{4}{*}{2.507} & \multirow{4}{*}{0.059} \\
\hline & $S$ and $E S R B$ & 3.20 & 1.42 & & \\
\hline & Šumadija and W SRB & 3.57 & 1.22 & & \\
\hline & Vojvodina & 3.64 & 1.03 & & \\
\hline
\end{tabular}

Source: Survey and own calculations

to have more precise image about the world and certainty of some social process. Doronina (1995) drew attention to necessity of studying psychological consequences caused by computerization.

Each language is developing and changing (McMahon, 1994; Brinton and ClossTraugott, 2005; Bialystok, 2013). Serbian language is full of foreign words of different origin, but this occurs in many other languages at the Balkan (Lakić, 2008; Šehović, 2009; Kostanjevac, 2009; Halonja, Mihaljević, 2012). Computer literacy has 'brought' many foreign words. It number of Anglicism that was adjusted to the rules of the Serbian language (gender, numerals and cases). This attitude is mostly accepted by the young $(\mathrm{M}=4.04)$ and they have shown mutual agreement $(\sigma=0.99)$. Mainly students population (20-24), had higher level of agreement $(M=4.25)$ in comparison to the others (Table 6). By studying a variet yof science, they have access to different information. Young people from the Region of the South and East Serbia were uncertain about this attitude and mutually disagreed $(\sigma=1.38)$. Such result was influenced by replies of smaller number of young people.

Computer literacy enabled disrespect of spelling rules. Usage of computers brought the enlargement of foreign words (Šehović, 2009) because adequate translation often does not exist in Serbian language. Writing of foreign words caused occurrence of spelling problems. They can be overcome very quickly, because there is software for checking spelling rules correctness. Language which appears in electronic business correspondence do not differs a lot from the language of traditional business correspondence.

Young people often use specific orthography which is mostly based on replacement of the most letters by similar ones (Halonja, Mihaljević, 2012). Marković, 
Table 6. Post-hoc Tukey HSD test forattitudes where the one-factor analysis ANOVA indicated the differences between age categories (MSE - mean square error, q-relevant critical value of the studentized range statistic, n-number of scores used in calculating the group means of interest, according to the Tukey table (2014), p $>0.01$, sign not important)

\begin{tabular}{|c|c|c|c|c|}
\hline Tukey HSD & $H S D=q \cdot \sqrt{\frac{M S E}{n}}$ & $\begin{array}{c}\text { Modern life cannot } \\
\text { be imagined without } \\
\text { computer literacy }\end{array}$ & $\begin{array}{l}\text { I am sure that I could } \\
\text { help anybody to } \\
\text { become computer } \\
\text { literate }\end{array}$ & $\begin{array}{l}\text { I am not sure that I will } \\
\text { be able to follow in future } \\
\text { further development of } \\
\text { computer literacy }\end{array}$ \\
\hline \multicolumn{2}{|l|}{$\mathrm{q}$ (from the table) } & \multicolumn{3}{|c|}{4.12 if $p<0.01$} \\
\hline \multicolumn{2}{|l|}{ MSE } & 1.335 & 0.9674 & 0.8972 \\
\hline \multicolumn{2}{|l|}{$n$} & 138.67 & & \\
\hline \multicolumn{2}{|l|}{ HSD } & 0.404247 & 0.34412 & 0.3314 \\
\hline \multicolumn{5}{|c|}{ Differences in mean values } \\
\hline $15-19$ & $20-24$ & -0.0957 & -0.3985 & -0.565 \\
\hline $15-19$ & $25-29$ & -0.775 & -0.632 & -0.234 \\
\hline \multirow[t]{2}{*}{$20-24$} & $20-29$ & -0.6789 & -0.2332 & 0.3312 \\
\hline & & $\begin{array}{c}\text { Computer literacy has } \\
\text { 'brought' many foreign } \\
\text { words }\end{array}$ & $\begin{array}{l}\text { Computer literacy } \\
\text { enabled disrespect of } \\
\text { spelling rules }\end{array}$ & \\
\hline \multicolumn{2}{|l|}{$\mathrm{q}$ (from the table) } & \multicolumn{3}{|c|}{4.12 if $p<0.01$} \\
\hline \multicolumn{2}{|l|}{ MSE } & 0.9493 & 1.305 & \\
\hline \multicolumn{2}{|l|}{$n$} & \multicolumn{3}{|c|}{138.67} \\
\hline \multicolumn{2}{|l|}{ HSD } & 0.3409 & 0.3996 & \\
\hline \multicolumn{5}{|c|}{ Differences in mean values } \\
\hline $15-19$ & $20-24$ & -0.354 & -0.5919 & \\
\hline $15-19$ & $25-29$ & 0.024 & -0.097 & \\
\hline $20-24$ & $20-29$ & 0.378 & 0.4953 & \\
\hline
\end{tabular}

Source: Survey and own calculations

Table 7. Post-hoc Tukey HSD test for attitudes where the one-factor analysis ANOVA indicated the differences between regions

\begin{tabular}{|c|c|c|c|c|}
\hline Tukey HSD & $H S D=q \cdot \sqrt{\frac{M S E}{n}}$ & $\begin{array}{l}\text { I am sure that I could } \\
\text { help anybody to } \\
\text { become computer } \\
\text { literate. }\end{array}$ & $\begin{array}{l}\text { I am not sure that I will } \\
\text { be able to follow in future } \\
\text { further development of } \\
\text { computer literacy. }\end{array}$ & $\begin{array}{c}\text { Computer literacy has } \\
\text { 'brought' many foreign } \\
\text { words. }\end{array}$ \\
\hline \multicolumn{2}{|l|}{$\mathrm{q}$ (from the table) } & \multicolumn{3}{|c|}{4.40 if $p<0.01$} \\
\hline \multicolumn{2}{|l|}{ MSE } & 1.001 & 0.9311 & 0.8906 \\
\hline \multicolumn{2}{|l|}{$n$} & \multicolumn{3}{|c|}{104.00} \\
\hline \multicolumn{2}{|l|}{ HSD } & 0.431671 & 0.416327 & 0.407171 \\
\hline \multicolumn{5}{|c|}{ Differences in mean values } \\
\hline Belgrade & S and E Ser & $-0,2857$ & 0,0572 & 0,7715 \\
\hline Belgrade & Sumadia and W Ser & $-0,298$ & $-0,402$ & $-0,074$ \\
\hline Belgrade & Vojvodina & $-0,4835$ & $-0,3472$ & $-0,0238$ \\
\hline S and E Ser & Sumadia and W Ser & $-0,0119$ & $-0,4596$ & $-0,8453$ \\
\hline S and E Ser & Vojvodina & $-0,1978$ & $-0,4044$ & $-0,7953$ \\
\hline Sumadia and W Ser & Vojvodina & $-0,1859$ & 0,0552 & 0,0500 \\
\hline
\end{tabular}

Source: Survey and own calculations. 
Prnjat (2011) pointed out that participants in computer communication simultaneously adopted, but created also the rules for using the language. For example, very often can be noticed the occurrence of: verb short forms, excessively using of punctuation marks, mistakes in writing, creative spelling, usage of abbreviations, using of capital letters in order to emphasizing the words etc. Because of informality email communication mistakes in writing are tolerated more often than in standard writing language. Mainly, mistakes in writing do not obstruct interpretation and understanding of message, nor in personal correspondence the credibility of senders' message with mistakes is questionable. Receivers of messages are aware of situation limits of e-mail communication (Crystal, 2001). Young examinees agreed about this attitude $(M=3.51)$, but they did not particularly mutually agree $(\sigma=1.17)$. Some of the young think that many make a lot of efforts, but failures are most often made because of ignorance than arrogance. Post-hoc Tukey HSD test has pointed out the student population (20-24 years old) who mostly agreed that computer literacy enabled disrespect of spelling rules, while the other young people in Serbia were not sure.

\section{Conclusion}

Computer literacy may be called phenomenon of present, because more than $4 / 5$ of young people in Serbia is computer literate, but some of them rarely had computing as the school subject. However, the schools try to follow modern educational courses. The speed and quality of work implementation in some kind of education and using computer literacy during educational process depends from size of the material means. Men are slightly more literate than women. Young people with less age have numerous populations of computer literate ones in comparison to the older ones. Almost 2/3 of computer literate ones live in the cities of Serbia. According to established regional differences, Belgrade is ahead in the share of computer literate in total number of young people while the Region of the South and East Serbia are in the back part. In direct correlation with number of computer literate could be made: number of the young in certain region, intensity of their immigration, possibility for employment, economic development and many other factors. In the survey, the young agreed that contemporary life cannot be imagined without computer literacy. They think that it is easily surmount and they were sure they could help to anyone in computer literacy. The young in Serbia agrees with the attitude that the computer literacy made possible disrespect of spelling rules as well as it 'brought' many foreign words.

\section{Acknowledgements}

This paper is part of the project No. 114-451-2539/201602 funded by the Provincial Secretariat for Higher Education and Scientific Research of the Vojvodina Province, Serbia. The authors are grateful to the reviewers, whose comments and criticisms have ensured the quality of the paper.

\section{References}

Akgun, A., Sezer, A.E., Nefeslioglu, A.H., Gokceoglu, C., Pradhan, B. 2012. An easy-to-use MATLAB program (MamLand) for the assessment of landslide susceptibility using a Mamdani fuzzy algorithm. Computers \& Geosciences 38-1, 23-34.

Beograd City authority 2015. Available online at: http://www.beograd.rs/g/images/520_opstine.gif (9.7.2015).

Bialystok, E. 2013. 25 The Impact of Bilingualism on Language and Literacy Development. The Handbook of Bilingualism and Multilingualism, 624 pp.

Bolter J.D. 2014. Writing space: Computers, hypertext, and the remediation of print. Routledge.

Bovée, C., Voogt, J., Meelissen, M. 2007. Computer attitudes of primary and secondary students in South Africa. Computers in Human Behavior 23-4, 17621776.

Brinton, J.L., ClossTraugott E. 2005. Lexicalization and language change. Cambridge University Press.

Bubalo Živković, M., Lukić, T. 2001. Mladi u Srbiji početkom 21. veka. Republički zavod za statisti$\mathrm{ku}$, Beograd.

Buckingham, D., Willett, R. 2013. Digital generations: Children, young people, and the new media. Routledge.

Byron Review 2008. The Byron Review: Safer Children in a Digital World. DCSF Publications.

Crystal, D. 2001. Language and the Internet. Cambridge, CUP.

Davis, D.F., Bagozzi, P.R., Warshaw, R.P. 1992. Extrinsic and intrinsic motivation to use computers in the workplace1. Journal of applied social psychology 2214, 1111-1132. DOI: 10.1111/j.1559-1816.1992.tboo945.x.

Delić, N. 2008. Informaciono-komunikacione tehnologije u obrazovanju. Panevropski univerzitet APERION. Banja Luka.

Dijanošić, B. 2008. Prilozi definiranju pojma funkcionalne pismenosti. Andragoški glasnik, Glasilo Hrvatskog andragoškog društva 13, 25-35.

Dimov, G., Zdravev, Z. 2011. Korišćenje online alatki za efikasno učenje u osnovnim it kursevima. Sixth International Symposium 'Technology, Informatics and Education for Learning and Knowledge Society', Technical Faculty Čačak, Serbia, 1-6 pp. 
Doronina, O.V 1995. Fear of computers. Russian Education \& Society 37-2, 10-28. DOI: 10.2753/RES10609393370210.

Duka, M., Mihailović, B., Miladinović, M., Janković, A., Živković, D., Vujičić, B. 2009. Evaluacija digitalne evidencije $\mathrm{u}$ oralnoj hirurgiji. PONS Med Journal 5-18, 19-23.

Đukičin, S., Đorđević, J., Milanković, J. 2014. Spatial and Social Changes Caused by the Continuous Exploitation of Lignite in the Kolubara Lignite Basin, Serbia. Acta Geographica Slovenica 54-1, 41-49. DOI: http://dx.doi.org/10.3986/AGS54102.

Gubin, S. 2010. Informatička pismenost u hotelskoj industriji. Departman za posle diplomske studije,Univezitet Singidunum, Beograd.

Halonja, A., Mihaljević, M. 2012. Novotvorenice u računalnome nazivlju. Jezik: časopis za kulturu hrvatskoga književnog jezika 59-3, 87-94.

Halonja, A., Mihaljević, M. 2012a. Od računalnoga žargona do računalnoga nazivlja. Institut za hrvatski jezik i jezikoslovlje, Zagreb.

Holmquist, L.E. 2013. The Zoom Browser: Showing Simultaneous Detail and Overview in Large Documents. Journal for Information Technology Studies as a Human Science 2-3, 1-14.

ICT 2015. Information and communication technology development index for Serbia and its surrounds. The International Telecommunication Union. Available online at http://www.itu.int/net4/ ITU-D/idi/ (18.8.2015).

Khan, M., Hossain, S., Hasan, M., Clement, C.K. 2012. Barriers to the Introduction of ICT into Education in Developing Countries: The Example of Bangladesh. Online Submission 5-2, 61-80.

Kostanjevac, D. 2009. Tuđice u publicističkom stilu. Hrvatistika 3, 39-48.

Lajoie, P.S., Derry, J.S. 2013. Computers as cognitive tools. Routledge.

Lakić, I., 2008. Anglicizmi u crnogorskom jeziku. Zbornik sa međunarodnog naučnog skupa 'Njegoševi dani'. Institut za jezik i književnost Filozofskog fakulteta, Cetinje, 321-328 pp.

Levy, F., Murnane, J.R. 2012. The new division of labor: How computers are creating the next job market. Princeton University Press.

Livingstone, S., Helsper, E. 2007. Gradations in digital inclusion: Children, young people and the digital divide. New media \& society 9-4, 671-696.

Lukić, T., Đurđev, B., Şahin, S., Plavša, J., Suljić, A., Stojsavljević, R. 2014. Turks in Vojvodina (Serbia), in the Second Half of the 2oth Century and on the Beginning of the 21st Century. Analele stiintifice ale Universitatii 'Alexandru Ioan Cuza' din Iasi-seria Geografie 6o-1, 185-199.
Lukić, T., Gavrilov, M.B., Marković, S.B., Komac, B., Zorn, M., Mlađan, D., Đorđević, J., Milanović, M., Vasiljević, Đ., Vujičić, M., Kuzmanović, B., Prentović, R. 2013. Classification of natural disasters between the legislation and application: experience of the Republic of Serbia. Acta geographica Slovenica 53-1, 149-164. DOI: http://dx.doi. org/10.3986/AGS53301.

Lukić, T., Jovanović, G., Bubalo Živković, M., Lalić, M., Đerčan, B. 2014a. Montenegrins in Vojvodina province, Serbia. Human Geographies - Journal of Studies \& Research in Human Geography 8-1, 43-54.

Maksimović, I. 2006. Obrazovanje menadžera za 21. vek. Univerzitet Singidunum, Beograd.

Marković, Lj., Prnjat, Z. 2011. Emailisms in Electronic Business Correspondence. Applied linguistics 12, 10-33.

Matović, M. 2011. Media literacy and children in new media environment. CM-časopis za upravljanje komuniciranjem 6-19, 53-66.

McMahon, MS. A. 1994. Understanding language change. Cambridge University Press.

Micić, T., Lukić, T., Đorđević, J., Basarin, B., Bjelajac, D., Hrnjak, I., Marković, S., Sakulski, D., Đerčan, B., Bubalo-Živković, M., Pavić, D., Lazić, L. 2014. Determination of Wind Energy Potential and its Implementation Concept for the Electricity Market in the Vojvodina Region (North Serbia)-An Overview. Geographica Pannonica 18-1, 6-17.

Mikarić, N.B., Trajković, D. 2013. Uticaj elektronskog poslovanja na poboljsanje usluga u bankarstvu. Trendovi u poslovanju 2, 69-80.

Milošević, D., Đorđević, J. 2015. Work zones of Novi Sad (Vojvodina, Serbia) with examples of industrial transformation. Geographica Pannonica 19-1, 31-41.

Nadrljanski, Đ. 2006. Informatička pismenost i informatizacija obrazovanja. Informatologija 39-4, 262266.

Obreht, I., Buggle, B., Catto, N., Marković, S.B., Bösel, S., Vandenberghe, D.A., Hambach, U., Svirčev, Z., Lehmkuhl, F., Basarin, B., Gavrilov, M.B., Jović, G. 2014. The Late Pleistocene Belotinac section (southern Serbia) at the southern limit of the European loess belt: Environmental and climate reconstruction using grain size and stable $\mathrm{C}$ and $\mathrm{N}$ isotopes. Quaternary International 334, 10-19. DOI:10.1016/j. quaint.2013.05.037.

Patterson, A.D., Hennessy, L.J. 2013. Computer organization and design: the hardware/software interface, Newnes.

Pearson, E.S., Hartley, H.O. 1966. Biometrika. Tables for Statisticians, third edition, 1-146 pp.

Radojković, M., Bekić, T. 2007. Put lokalne zajednice $\mathrm{u}$ informaciono društvo. Časopis za upravljanje komuniciranjem 2-2, 45-59. 
Raosoft 2004. Sample size calculator. Raosoft Inc. Available online at: http://www.raosoft.com/samplesize.html (3.4.2015.).

Rašidović, B. 2013. Informacijska pismenost-pravo na znanje i novi biblioteksrski aktivizam. Pregledčasopis za društvena pitanja 2, 133-150.

Rosenberg, S.R. 2013. The social impact of computers. Elsevier.

RZS 2013. Školska sprema, pismenost i kompjuterska pismenost. Popis stanovništva, domaćinstava i stanova u 2011. u Republici Srbiji, Republički zavod za statistiku, Beograd.

RZS 2015. Opštine u Republici Srbiji po oblastima i regionima, Republički zavod za statistiku, Beograd. Available online at http://webrzs.stat.gov.rs/
WebSite/userFiles/file/Opsti\%2opodaci\%2ou\%2O Republici\%2oSrbiji/Karte/Oblasti-1.1.2015.pdf (7.4.2015.).

Šehović, A., 'Mjesto i funkcija anglicizama u savremenom bosanskom jeziku', 2009, PismoČasopiszajezik i književnost, vol. 7, pp: 122-138.

Unković, M., Stakić, B. 2011. Spoljnotrgovinsko i deviznoposlovanje. Univerzitet Singidunum, Beograd.

Williamson, B. 2009. Computer games, schools, and young people: A report for educators on using games for learning. Bristol, Futurelab.

Zindović-Vukadinović, G.R., 1995. Educational technology: Problem of determination. Zbornik Instituta za pedagoška istraživanja 27, 230-246. 